\title{
巵eonomies
}

Central European Review of Economics \& Finance

Vol. 29, No. 1 (2019), pp. 5-22

DOI: $10.24136 /$ ceref.2019.001

Received: 10 January 2019. Accepted: 18 February 2019.

Katarzyna KACZMARCZYK ${ }^{1}$

\section{METHODS FOR CALCULATING LOAN PROFITABILITY FOR A BANK}

Credit activity is considered one of the most important tasks of the bank, both from the point of view of itself, as well as from the perspective of customers and the entire national economy. The banks transform the funds obtained from depositors and then transfer them to the borrowers. Before doing so, however, they carry out numerous analyzes and studies that make up credit procedures. The purpose of this article is to analyze and evaluate the methods of calculating the profitability of interest products for a bank in terms of the validity of their application.

Keywords: bank loan, efficiency, calculation.

JEL Classification Codes: G21.

\section{Introduction}

In the bank's management system, including pricing of loan products, an important issue is the assessment of the profitability of banking products. It helps, inter alia, in making both short- and long-term decisions, and also shows the strengths and weaknesses of the products offered, needed in the process of shaping the pricing policy. This assessment is also important from the point of view of bank management, which requires making multiple decisions regarding both current and strategic goals. Thanks to such calculations, the bank receives information about the quality and usability of individual areas of its operations. This allows you to increase the rationality of decisions made, which results in an increase in the bank's value.

\footnotetext{
${ }^{1}$ Ph.D. Student, K. Pulaski University of Technology and Humanities in Radom, Faculty of Economics and Legal Sciences.
} 
The aim of the study is to analyze and evaluate the methods of calculating the profitability of interest products at the bank, on the example of the calculation of the effectiveness of active products.

\section{Credit activity as the main source of bank's income}

The Bank is an independent and self-funded enterprise whose main goal is to maximize profits. It focuses on all of its activities, seeking to acquire and retain customers who bring him the highest income, and at the same time bring the least risk.

The main sources of the bank's income include:

- interest on loans granted;

- bank commissions and fees;

- income from trading in securities;

- income from deposits placed in other banks;

- income from other services provided.

However, the largest source of income from the listed elements are loans granted. As a creditor, the bank derives benefits in the form of interest, being the equivalent of the costs of obtaining funds, which are absolutely necessary to provide it, as well as a commission that is reward for all activities related to the credit transaction (Wąsowski 2001, p. 46).

Table 1 presents a comparison of the actual numerical data from analogous periods in 2016 and 2017, showing the size of income of the banking sector in Poland due to banking activity.

Table 1. Selected elements of the results for the banking sector in Poland

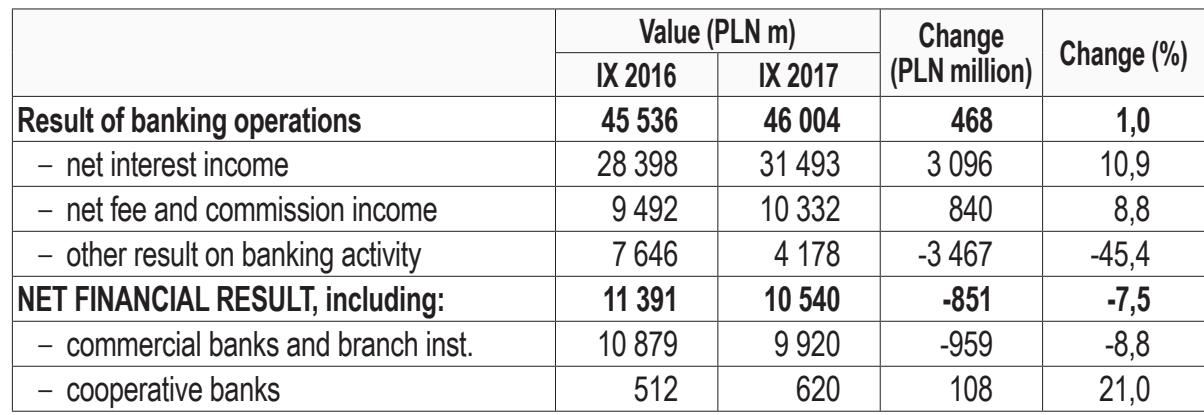

Source: own elaboration based on the report on the situation of the banks of the Financial Supervision Authority 2017.

In the period from January to September 2017, the result of banking operations in Poland improved by PLN 468 million (1.0\%), mainly due to the completion of a record interest result (PLN 31,493 million), up by almost 11\% from the result achieved in the 
same last year. This was mainly due to recent changes in the deposit and credit policy in the recent periods, consisting in lower interest rates on deposits and, at the same time, higher interest rates on most loans (Office of the Polish Financial Supervision Authority, 2017).

There was also an improvement in net fee and commission income. In October 2017. this figure was PLN 10,332 million, which is $8.8 \%$ better than in the same period of 2016. It resulted, among others, from the increase in revenues from loans and credits granted, sale of insurance products, servicing bank accounts or investment funds (Office of the Polish Financial Supervision Authority, 2017).

A significant drop in value in the item covering the remaining activities of the bank (-3 467 million PLN), is in particular the effect of settlement in the second quarter of 2016. sale of shares in VISA Europe Limited, which was an additional income of PLN 2465 million) (Office of the Polish Financial Supervision Authority, 2017).

Ultimately, however, whether a bank makes a profit (a positive net financial result) or a loss (a negative net financial result) decides a number of components. In addition to the results of banking operations, they include costs of the bank's operations, depreciation, balance of provisions and allowances, or results of operating activities. In the period from January to September 2017, the net financial result of the banking sector in Poland amounted to PLN 10,540 million and it was PLN 851 million (7.5\%) less than it was achieved in the corresponding period of the previous year. This result was mainly the result of the aforementioned sale of shares in VISA Europe Limited. If it were not for these activities, the net financial result would certainly be higher than that achieved in the corresponding period of 2016. (Office of the Polish Financial Supervision Authority, 2017).

The analysis of the above data shows how important, due to the bank's income, is the credit activity and what is connected with it - the methodology for assessing the profitability of banking products. It applies to active and passive balance products, ie those related to raising capital as well as its involvement in active products. Off-balance sheet items, eg guarantees or derivative instruments, are not taken into account in this case. The main idea of this methodology is that the product's profitability is determined by the average cost of obtaining financing sources, taking into account the bank's reserve and operating costs. The result of such an assumption is the calculated margin, which is a measure of effectiveness (Wąsowski 2001, p. 194).

\section{Methodology for assessing customer effectiveness}

Each of the transactions concluded by the bank affects the financial result. For this reason, the effectiveness of the transaction is so important in the assessment of effectiveness. When it is conducted with clients, the bank may first determine the benefits it wants to achieve as a result of these activities. The main task of the efficiency calcula- 
tion is to determine the long-term lower price limit, also taking into account the actual costs. Thanks to this calculation, the bank has the opportunity to modify its position on subsequent transactions. In individual cases, when prices are shaped by the market, the bank is forced to accept an ineffective transaction, however important from the point of view of further cooperation with a given customer. Earlier, however, he makes an assessment of how the result of the bank would affect the resignation of these activities. It can be argued that the bank's operating costs are to a large extent fixed costs, which in the perspective of further cooperation with the client affects the acceptance of the transaction, but not always. You can meet estimates that $80 \%$ of clients give $20 \%$ of losses, or $20 \%$ of clients give $80 \%$ of profits (Wąsowski 2001, p. 199).

The effectiveness of cooperation with the client in the scope of the bank's credit activities can be determined by calculating individual components, such as:

- interest income;

- financing costs according to market rates;

- operating costs;

- the cost of risk (Wasowski 2001, p. 199).

The main cost associated with the loan is the interest rate. It depends on the total value of accrued interest that the client pays on the loan taken, as well as the amount of the installments. It also affects the creditworthiness, which should be the higher the lower the interest rate on the loan. The interest rate is determined on the basis of the base (reference) rate and the bank's margin. The reference rate is the yield on the NBP bills issued by the National Bank of Poland in conducting open market operations. In other words, it is the interest rate at which the largest banks grant loans to other banks on the international market. The base rate for loans in the Polish currency is WIBOR (1M, 3M or $6 \mathrm{M}$, for loans in PLN), EURIBOR (1M, 3M or $6 \mathrm{M}$, for loans granted in EUR) and LIBOR (1M, 3M, or 6M, for loans granted in US dollars). This form is called the nominal interest rate. There is also a concept of real interest, which also includes other charges, such as commission and often insurance. These factors are of particular importance to consumers.

In order to determine the final interest rate, the bank adds a margin to the market reference rate. It constitutes the bank's remuneration for borrowed money. Its amount is determined individually by each bank depending on the policy adopted by it, taking into account several criteria, including loan amount, purchase of additional products (credit card) or negotiations with the bank. Margin is determined before the loan agreement is signed, and then it is fixed throughout the loan period. Its change is possible only in the form of an annex to the contract (Czerwiński, 2011).

However, the margin size will not help in determining the actual impact on the financial result, taking into account the scale of the given instrument. The financial instrument, which is characterized by a low margin or profitability but a high share, is more 
binding than an instrument with a high margin, but a small share (Wąsowski 2001, p. 194).

An example of loan profitability calculation for a bank is presented in Table 2.

Table 2. Example of customer efficiency assessment for active transaction - credit

\begin{tabular}{|l|c|c|c|c|c|c|c|c|}
\hline & Value & $\begin{array}{c}\text { Rate } \\
\%\end{array}$ & $\begin{array}{c}\text { Market } \\
\text { rate }\end{array}$ & $\begin{array}{c}\text { Profit margin } \\
\%\end{array}$ & Income & $\begin{array}{c}\text { Operating } \\
\text { costs }\end{array}$ & $\begin{array}{c}\text { The cost } \\
\text { of risk }\end{array}$ & $\begin{array}{c}\text { The final } \\
\text { income }\end{array}$ \\
\hline Active transaction-Credit & 3000 & 22 & 20 & 2 & 60 & 15 & 5 & 40 \\
\hline
\end{tabular}

Source: own study based on Wąsowski 2001, p. 200.

According to the sample calculation presented in Table 2, although the bank, after determining the interest rate, can calculate the income it receives from a given loan, to estimate the final income, it must include additional operating costs and risk costs. In practice, the often-appearing term is the APRC, which means nothing more than the already mentioned annual percentage rate of interest. It should take into account all the basic costs borne by the borrower in connection with the concluded loan agreement. It is mainly about:

- loan interest rate;

- commissions for lending;

- insurance;

- payment for additional services (eg consultant visit at home);

- payment for processing a loan application;

- changes in the value of money over time and the repayment period.

In many banks, in the case of loans to people and housing, the interest rate is set at the same level for all clients, although it happens that it is calculated individually depending on the client's assessment. In the case of commercial loans, the rule is to differentiate the loan based on the risk assessment associated with a given client (Dobosiewicz 2007, p. 169). Risk is a common phenomenon in bank activities. It is of a complex and multi-dimensional nature. Majority of risk factors derive from information asymmetry. This phenomenon consists in the fact that the scope of information which is in the possession of the parties entering into transaction is varied (Olszewska 2018, p. 68). The higher the risk borne by the bank, the higher the interest rate is set, which in practice means transferring risk to the client (Dobosiewicz 2007, p. 169).

The following factors affecting the cost of the loan can be distinguished:

- loan period;

- individual customer assessment by the bank;

- the bank's policy regarding the loan portfolio;

- quality of security (Dobosiewicz 2007, p. 169). 
Banks make a detailed individual analysis of the financial situation of the client before granting him a loan. The lower interest rates can be found in the more affluent, more dynamic companies, long-term cooperation with the bank, commercial banks on which the bank earns through various settlements, but also those clients that the bank wants to win. By the way, the bank raises the interest rate on loans to customers, which it will identify as particularly risky (Dobosiewicz 2007, p. 169).

Another factor having a significant impact on the cost of the loan is the bank's policy regarding the loan portfolio. Banks do not have the ability to have specialists who can assess every area of the economy. The assessment of loan applications from some of them is so problematic that it requires raising their price. And vice versa. Credits in areas where the risk of making a mistake is smaller are cheaper (Dobosiewicz 2007, p. 169).

An equally important rule applicable when calculating the cost of a loan is to refer to the quality of collateral for a given loan. The more questionable their quality, the higher the interest rate charged (Dobosiewicz 2007, p. 169).

\section{Methods for calculating the profitability of loans for a bank}

\section{Traditional methods for assessing the effectiveness of interest products}

A very important role in the bank's management system, including pricing of loan products, is the assessment of the profitability of banking products. It helps in taking both short- and long-term decisions, shows the strengths and weaknesses of the products offered for the pricing policy process, setting the planned balance sheet structure, or identifying the reasons for a possible drop in the profitability of products and the search for its solutions (Szadziewska, 2005). In order to determine the interest margin for the activity conducted by the bank on the basis of data from financial accounting, an interest balance is prepared, containing average assets and liabilities with their interest rate. However, this balance shows only a general picture of how individual balance sheet items affect the total net interest income of the bank. In order to determine the share of banking products on the total interest margin, two groups of methods are used: traditional and market-based. The first group includes the one pool method and the layered balance method. On the other hand, the group of market methods contains only the method of market interest (Iwanicz-Drozdowska 1999, p.109).

The method of one pot assumes that:

- liabilities form one pool that finances active operations, irrespective of the selling periods and interest rates,

- assets form the second pool, thus constituting a portfolio of deposits for acquired liabilities, regardless of their differentiation. 
The total interest margin creates in this case the difference between the average interest rate on assets and liabilities. Financing of active operations is carried out at the average cost of obtaining liabilities, whereas passive operations are invested at the average interest rate on assets. On this basis, it is possible to determine the individual margins of individual items. In order to calculate the margin achieved on specific products - assets, two formulas are used:

\section{METOD 1}

$$
M=\frac{r_{A}-r_{P}}{2}
$$

where:

$\mathrm{M}$ - margin

$r_{A}$ - interest rate on assets

$\Delta r_{p}$ - average interest on liabilities

\section{METOD 2}

$$
M=r_{A}-\Delta r_{P}-\frac{M C}{2}
$$

where:

$\mathrm{M}$ - margin

$\mathrm{r}_{\mathrm{A}}$ - interest on an asset item

$\Delta \mathrm{r}_{\mathrm{p}}$ - average interest on liabilities

$\mathrm{MC}$ - total margin

In the case of liabilities, formula formulas change, but the principle of sharing the margin developed by the bank on two sides of the balance sheet is maintained. Each of them is allocated half of the total margin. Method 2, however, allows for a more stringent evaluation of banking products, showing products with negative and near-zero, as well as very high margins (Iwanicz-Drozdowska 1999, p.112).

Table 3 shows the advantages and disadvantages of the one pool method.

Table 3. Evaluation of the one pool method

\begin{tabular}{|l|l|l|}
\hline $\begin{array}{c}\text { Measurement } \\
\text { method }\end{array}$ & \multicolumn{1}{|c|}{ Benefits } & \multicolumn{1}{c|}{ Disadvantages } \\
\hline One pool method & - simple to use & - does not take into account the relationship between \\
& - assets are assigned to a portion of & individual items of assets and liabilities \\
& interest costs, while part of rev- & - the contribution of active operations to the bank's result \\
& enues is allocated to liabilities & depends on the pricing policy applied to liabilities, and \\
& - makes it possible to evaluate the & the contribution of passive operations to the result \\
& effectiveness of individual interest & depends on the bank's investment policy \\
& products & - does not take into account current market conditions \\
\hline
\end{tabular}

Source: own study based on https://metafinanse.pl/co-to-jest-rrso-kredyt-koszty/ 
The second traditional method used to measure the profitability of products is the layered balance method. It does not give the opportunity to estimate the effectiveness of each of the balance products, but the balance sheets. These layers are distinguished on the basis of three criteria:

- profitability (interest rates on assets and liabilities);

- liquidity;

- compliance with prudential norms affecting the structure of assets and liabilities (Iwanicz-Drozdowska 1999, p.114).

In the case of the first criterion, which is the interest rate, there is the problem of allocating the required reserve. It can be placed in the layer of assets with the lowest interest rate, as well as in the layers with liabilities, from which a specific part of the reserve is discharged. The next criterion - liquidity, assigns balance sheet items to specific layers based on contractual dates or dates remaining until the end of the transaction (maturities). Sometimes, however, it is impossible to specify such terms (Iwanicz-Drozdowska 1999, pp. 114-115).

The tiered layer method, by means of linking specific items of assets and liabilities, illustrates the impact of particular layers on the global interest margin. However, it does not help in assessing the profitability of banking products. In addition, it is possible to create problems when interpreting the results. Table 4 shows the advantages and disadvantages of the stratified balance method.

Table 4. Evaluation of the stratified balance method

\begin{tabular}{|c|c|c|}
\hline $\begin{array}{l}\text { Measurement } \\
\text { method }\end{array}$ & Benefits & Disadvantages \\
\hline $\begin{array}{l}\text { Layer balance } \\
\text { method }\end{array}$ & $\begin{array}{l}\text { - allows to estimate, } \\
\text { - effectiveness of balance sheet } \\
\text { layers, } \\
\text { - takes into account the relation- } \\
\text { ship between asset and liability } \\
\text { items. }\end{array}$ & $\begin{array}{l}\text { - it does not show the effectiveness of individual bank- } \\
\text { ing products, } \\
\text { - there is no unambiguous division into layers (there } \\
\text { are several ways to divide), } \\
\text { - does not take into account market conditions at the } \\
\text { time the transaction is made }\end{array}$ \\
\hline
\end{tabular}

Source: own study based on https://metafinanse.pl/co-to-jest-rrso-kredyt-koszty/

\section{Market methods for assessing the effectiveness of interest products}

The market method for assessing the effectiveness of interest products is the market interest method (interest rate method). It was first used in the 1970s in American money-center banks to assess the effectiveness of loans granted and deposits accepted (Iwanicz-Drozdowska 2010, p.98).

It is based on the assumption that an alternative transaction on the financial market is possible for every active or passive transaction. Her main goals are: 
- calculation of margins on transactions or portfolio of transactions, as well as an assessment of their impact on the total bank's margin;

- determining the pricing policy;

- providing bank managers with information on the valuation of transactions that do not meet expectations in this area (Iwanicz-Drozdowska 2010, p.9899).

Determining the profitability of the effectiveness of individual active positions using the bank interest method takes place in practice according to the scheme shown in Figure 1.

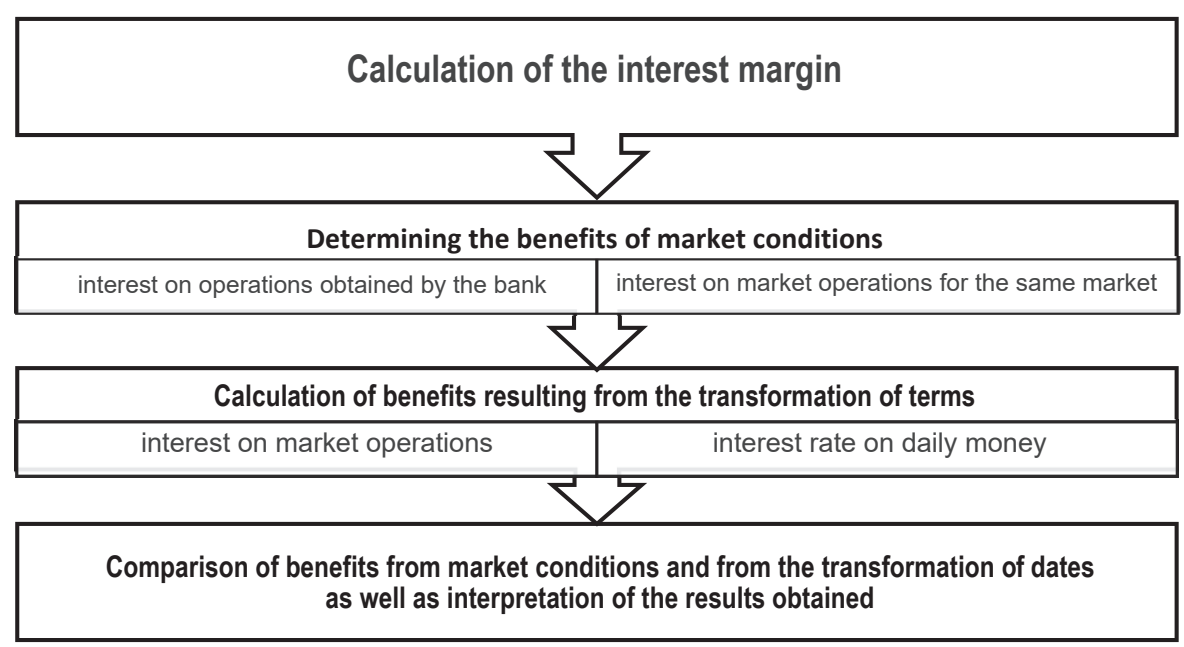

Figure 1. Stages of the calculation of the effectiveness of banking products using the market interest method

Source: own study based on https://metafinanse.pl/co-to-jest-rrso-kredyt-koszty/

The total interest surplus in this case can therefore be divided into three groups of benefits: resulting from market conditions, from the transformation of dates and from the transformation of currencies. They are estimated based on the concept of "costs of lost profits". The interest surplus on active transactions can be recorded using the formula:

where:

$$
M O D_{A}=r_{\text {trans }}-r_{\text {alt }}
$$

$M O D_{A}$ - interest margin on active transactions

$r_{\text {trans }}$ - interest rate obtained from the transaction

$r_{\text {alt }}$ - alternative interest rate 
The results obtained from the assessment carried out using the market interest method provide a source of information for the assessment of individual products as well as organizational units and clients (Iwanicz-Drozdowska 2010, pp. 98-99).

The application of the interest rate method allows for taking into account market conditions in the process of calculating the effectiveness of interest products. The possibility of using it also for the assessment of organizational units or specific clients increases its usefulness in banking practice (https://metafinanse.pl/co-to-jest-rrso-kredyt-koszty/).

The features of the market interest method in the form of a presentation of advantages and disadvantages are summarized in Table 5.

Table 5. Evaluation of the market interest method

\begin{tabular}{|c|c|c|}
\hline $\begin{array}{l}\text { Measurement } \\
\text { method }\end{array}$ & Benefits & Disadvantages \\
\hline $\begin{array}{l}\text { Market interest } \\
\text { method }\end{array}$ & $\begin{array}{l}\text { - takes into account the current market } \\
\text { conditions, thanks to which it allows to } \\
\text { estimate whether the completed trans- } \\
\text { action was concluded on terms more } \\
\text { or less favorable to those prevailing on } \\
\text { the market, } \\
\text { - helps to set a minimum interest rate in } \\
\text { terms of achieving the planned result, } \\
\text { and thus making a decision about } \\
\text { concluding a given transaction, } \\
\text { - It allows not only to carry out the cal- } \\
\text { culation of the effectiveness of banking } \\
\text { products, but also the bank's clients } \\
\text { and organizational units. }\end{array}$ & $\begin{array}{l}\text { - the difficulty of obtaining information by the } \\
\text { bank about the interest rates sought, } \\
\text { - a free capital and money market is assumed, } \\
\text { which is not always true, } \\
\text { - it is not an instrument for managing the balance } \\
\text { sheet structure, because it does not ensure } \\
\text { automatic coordination of assets and liabilities, } \\
\text { - no possibility of calculating new transactions in } \\
\text { isolation from previously concluded transactions } \\
\text { (jointly determines revenues from past and } \\
\text { future transactions). }\end{array}$ \\
\hline
\end{tabular}

Source: own study based on https://metafinanse.pl/co-to-jest-rrso-kredyt-koszty/

The discussed both traditional and market methods for assessing the effectiveness of active products form the basis for the simulated calculation of the effectiveness of banking products.

\section{Simulation calculation of the effectiveness of interest products}

\section{One pool method}

In order to more fully discuss the methods of calculating the effectiveness of active products based on them, exemplary simulations have been developed. As the basis for calculations in these methods is the interest balance, it was presented as the first in Table 6 and will be used to perform the simulation using the single pool method. 
Table 6. Interest rate balance of a commercial bank $X$

\begin{tabular}{|c|c|c|c|c|c|}
\hline Assets & Value & $\begin{array}{c}\text { Average } \\
\text { interest rate }\end{array}$ & liabilities & Value & $\begin{array}{c}\text { Average } \\
\text { interest rate }\end{array}$ \\
\hline $\begin{array}{l}\text { 1. Cash, operations with the Cen- } \\
\text { tral Bank }\end{array}$ & 382,00 & 0,00 & $\begin{array}{l}\text { 1. Liabilities due to the Central } \\
\text { Bank }\end{array}$ & 110,00 & 14,50 \\
\hline $\begin{array}{l}\text { 2. Receivables from the financial } \\
\text { sector: }\end{array}$ & 955,00 & & $\begin{array}{l}\text { 2. Liabilities to the financial } \\
\text { sector: }\end{array}$ & 783,00 & \\
\hline - up to three months & 594,00 & 4,50 & - up to 3 months & 211,00 & 3,50 \\
\hline - above 3 months to 1 year & 284,00 & 6,50 & - above 3 months to 1 year & 532,00 & 5,25 \\
\hline - over 1 to 5 years & 57,00 & 9,50 & - over 1 to 5 years & 28,00 & 7,85 \\
\hline - over 5 years & 20,00 & 12,00 & - over 5 years & 12,00 & 10,25 \\
\hline $\begin{array}{l}\text { 3. Receivables from the non- } \\
\text { financial sector: }\end{array}$ & 3375,00 & & $\begin{array}{l}\text { 3. Liabilities to the non-finan- } \\
\text { cial sector: }\end{array}$ & 6175,00 & \\
\hline - up to 3 months & 203,00 & 6,50 & - up to 3 months & 3149,00 & 4,75 \\
\hline - above 3 months to 1 year & 539,00 & 11,50 & - above 3 months to 1 year & 2594,00 & 9,25 \\
\hline - over 1 to 5 years & 1284,00 & 13,85 & - over 1 to 5 years & 373,00 & 12,50 \\
\hline - over 5 years & 1349,00 & 16,15 & - over 5 years & 59,00 & 15,15 \\
\hline $\begin{array}{l}\text { 4. Receivables from the public } \\
\text { sector: }\end{array}$ & 730,00 & & $\begin{array}{l}\text { 4. Liabilities to the public } \\
\text { sector: }\end{array}$ & 424,00 & \\
\hline - up to 3 months & 11,00 & 5,80 & - up to 3 months & 382,00 & 4,20 \\
\hline - above 3 months to 1 year & 192,00 & 9,60 & - above 3 months to 1 year & 15,00 & 8,50 \\
\hline - over 1 to 5 years & 365,00 & 11,75 & - over 1 to 5 years & 17,00 & 8,75 \\
\hline - over 5 years & 162,00 & 15,50 & - over 5 years & 10,00 & 10,25 \\
\hline 5. Securities & 2857,00 & 12,50 & 5. Liabilities from securities & 252,00 & 10,25 \\
\hline 6. Intangible assets & 27,00 & 0,00 & 6. reserves & 128,00 & 0,00 \\
\hline 7. Tangible fixed assets & 211,00 & 0,00 & 7. Equity capital & 665,00 & 0,00 \\
\hline $\begin{array}{l}\text { Sum / Average weighted interest } \\
\text { rate }\end{array}$ & 8537,00 & 11,34 & $\begin{array}{l}\text { Sum / Average weighted inter- } \\
\text { est rate }\end{array}$ & 8537,00 & 6,39 \\
\hline
\end{tabular}

Source: own study based on https://metafinanse.pl/co-to-jest-rrso-kredyt-koszty/

In Table 6, you can find not only amounts and weighted averages of interest rates on assets, but also liabilities that are necessary to make calculations using selected methods. First, however, you can calculate the total interest margin.

where:

$$
M O D=r_{A}-r_{p}
$$

$M O D$ - gross interest margin

$r_{A}$ - interest rate on assets

$r_{p}$ - interest on liabilities

$\mathrm{MOD}=11,34 \%-6,39 \%$ 


\section{Interest margin $=4.95 \%$}

Based on the data from table 6 and the formulas, partial margins can be estimated. The results of the calculation are presented in Table 7.

Table 7. Example calculations of partial margins for selected asset items using the single pool method

\begin{tabular}{|l|l|l|}
\hline \multicolumn{1}{|c|}{ Assets } & \multicolumn{1}{|c|}{ Interest margin - METHOD 1 } & \multicolumn{1}{|c|}{ Interest margin - METHOD 2 } \\
\hline 1. Receivables from the financial sector: \\
\hline - up to 3 months & $(4,50 \%-6,39 \%) / 2=-0,945 \%$ & $4,50 \%-6,39 \%-2,475 \%=-4,365$ \\
\hline - above 3 months to 1 year & $(6,50 \%-6,39 \%)=0,055 \%$ & $6,50 \%-6,39 \%-2,475 \%=-2,365 \%$ \\
\hline - over 1 to 5 years & $(9,50 \%-6,39 \%) / 2=1,555 \%$ & $9,50 \%-6,39 \%-2,475 \%=0,635 \%$ \\
\hline - over 5 years & $(12,00 \%-6,39 \%) / 2=2,805 \%$ & $12,00 \%-6,39 \%-2,475 \%=3,135 \%$ \\
\hline 2. Receivables from the non-financial sector: \\
\hline - up to 3 months & $(6,50 \%-6,39 \%)=0,055 \%$ & $6,50 \%-6,39 \%-2,475 \%=-2,365 \%$ \\
\hline - above 3 months to 1 year & $(11,50 \%-6,39 \%)=2,555 \%$ & $11,50 \%-6,39 \%-2,475 \%=2,635 \%$ \\
\hline - over 1 to 5 years & $(13,85 \%-6,39 \%)=3,73 \%$ & $13,85 \%-6,39 \%-2,475 \%=4,985 \%$ \\
\hline - over 5 years & $(16,15 \%-6,39 \%)=4,88 \%$ & $16,15 \%-6,39 \%-2,475 \%=7,285 \%$ \\
\hline
\end{tabular}

Source: Own study based onhttps://metafinanse.pl/co-to-jest-rrso-kredyt-koszty/

As you can see, the type of counting method used allows you to get different results. However, taking into account the amount of partial margins obtained, the order of interest products in terms of their profitability is the same. Receivables from the non-financial sector with a repayment date of over 5 years turned out to be the most profitable. In the process of analyzing the results obtained, the marginal mark is of particular importance. In the case of results close to zero, or below zero, this is a signal of low efficiency or even ineffectiveness of a given product.

\section{Layer balance method}

The basis for the next simulations will be a somewhat simplified layout of another interest balance, which is presented in Table 8 .

Table 8. The system of interest balance of the commercial bank $Y$

\begin{tabular}{|l|r|c|l|r|c|}
\hline \multicolumn{1}{|c|}{ Assets } & Value & $\begin{array}{c}\text { Average } \\
\text { interest rate }\end{array}$ & \multicolumn{1}{|c|}{ liabilities } & Value & $\begin{array}{c}\text { Average } \\
\text { interest rate }\end{array}$ \\
\hline $\begin{array}{l}\text { 1. Cash and bill at the central bank } \\
\text { in }\end{array}$ & 150,00 & 0,00 & 1. Deposits a vista & 320,00 & 7,00 \\
\hline $\begin{array}{l}\text { 2. Receivables from clients (12 } \\
\text { months) }\end{array}$ & 650,00 & 24,50 & 2. Term deposits (6 months) & 550,00 & 19,50 \\
\hline $\begin{array}{l}\text { 3. Value parcels (6 months) } \\
\begin{array}{l}\text { Sum / Average weighted interest } \\
\text { rate }\end{array}\end{array}$ & 200,00 & 19,00 & 3. Issued securities (6 months) & 130,00 & 17,00 \\
\hline
\end{tabular}

Source: own study based on Iwanicz-Drozdowska 1999, p. 109. 
According to the assumptions of the stratified balance method, it is necessary to calculate the margin for particular layers of the balance sheet, after prior arrangement in accordance with the interest rate as well as the manner of allocating the required reserve. In this case, the layers were shaped on the basis of asset items, and the mandatory reserve was included in the last layer (Iwanicz-Drozdowska 1999, p. 109). Necessary mandatory reserves are presented in Table 9.

\section{Table 9. Reserve requirement}

\begin{tabular}{|l|c|c|}
\hline \multicolumn{1}{|c|}{ Reserve requirement } & $\%$ & Amount \\
\hline Depositsa vista & 20,11 & 64,00 \\
\hline Term deposits & 11,00 & 60,50 \\
\hline Issued securities & 11,00 & 11,00 \\
\hline
\end{tabular}

Source: own study based on Iwanicz-Drozdowska 1999, p. 116.

The following tables 10,11 and 12 contain the assignment according to the interest rate to individual layers when the reserve requirement is included in the last band.

Table 10. Layer I

\begin{tabular}{|l|c|c|}
\hline \multicolumn{1}{|c|}{ Specification } & $\%$ & Amount \\
\hline Receivables from clients (12M) & 24,5 & 650,00 \\
\hline Total layer I & 24,5 & 650,00 \\
\hline Term deposits (6M) & 19,50 & 550,00 \\
\hline Issued securities (6M) & 17,50 & 130,00 \\
\hline Total layer I & 19,12 & 680,00 \\
\hline Layer margins & $\mathbf{5 , 3 8}$ & \\
\hline
\end{tabular}

Source: own study based on Iwanicz-Drozdowska 1999, p. 116.

Table 11. Layer II

\begin{tabular}{|l|r|r|}
\hline \multicolumn{1}{|c|}{ Specification } & $\%$ & Amount \\
\hline Securities (6M) & 19,00 & 200,00 \\
\hline Total layer II & 19,00 & $\mathbf{2 0 0 , 0 0}$ \\
\hline Surplus from layer I & 19,12 & 30,00 \\
\hline deposits a vista & 7,00 & 320,00 \\
\hline Total layer II & $\mathbf{8 , 0 4}$ & $\mathbf{3 5 0 , 0 0}$ \\
\hline Layer margins & $\mathbf{1 0 , 9 6}$ & \\
\hline
\end{tabular}

Source: own study based on Iwanicz-Drozdowska 1999, p. 117. 
Table 12. Layer III

\begin{tabular}{|l|c|c|}
\hline \multicolumn{1}{|c|}{ Specification } & $\%$ & Amount \\
\hline Reserves required from contributionsa vista & 0,00 & 64,00 \\
\hline Mandatory reserves on term deposits (6M) & 0,00 & 60,50 \\
\hline Mandatory reserves on securities issued (12M) & 0,00 & 11,00 \\
\hline Cash and a bill at the central bank & 0,00 & 14,50 \\
\hline Total layer III & $\mathbf{0 , 0 0}$ & $\mathbf{1 5 0 , 0 0}$ \\
\hline Surplus from layer II & 8,04 & 150,00 \\
\hline Total layer III & $\mathbf{8 , 0 4}$ & $\mathbf{1 5 0 , 0 0}$ \\
\hline Layer margins & $\mathbf{- 8 , 0 4}$ & \\
\hline OVERALL MARGIN & $\mathbf{4 , 4 9}$ & \\
\hline
\end{tabular}

Source: own study based on Iwanicz-Drozdowska 1999, p. 117.

The presented simulation showed that the assets with the highest interest rate are receivables from customers $(24.5 \%)$, while liabilities - term deposits $(19.5 \%)$ and they were in the first layer of the balance sheet. However, due to the fact that the amounts of these items are not equal, it was necessary to equalize the amount of the layer. This was done by adding to the term deposits the second highest position of liabilities in terms of the interest rate. After the operation of adding to the layer I issued securities $(17.5 \%)$, there was a surplus on the liabilities side, which is transferred to the lower layer. For Tier I, the weighted average interest rates on assets (24.5\%) and liabilities $(19.12 \%)$ were calculated. The difference between these results is the margin of the layer and amounts to $5.38 \%$.

Layer II consists of assets and liabilities with an average interest rate. In addition, there was a surplus from layer I in the form of thirty monetary units (19.12\%). The procedure in this layer is identical to the previous one. The difference occurred in the case of layer III. First of all, the surplus from Tier II occurred on the liabilities side. Secondly, there was a total margin position. Its calculation is carried out counting the weighted average margin of individual layers. The condition is, however, to take into account when weighing the amounts reported for each layer on the asset side.

Traditional methods of calculating the effectiveness of interest products do not take into account prevailing market conditions at the time the transaction is concluded. It is not compared whether the effects achieved by the bank were worse than those possible to achieve on the market or whether they could be better. This defect can be eliminated using the market interest method. 


\section{Market interest method}

An example of the calculation of the effectiveness of interest products using the last of the discussed methods - the market interest method, was developed based on the $Y$ commercial bank interest balance and assumptions that the market interest rates for assets and liabilities are the same and the calculations are made annually. This variant is shown in table 13.

Table 13. Market interest method - simulation

\begin{tabular}{|l|r|r|r|r|}
\hline \multicolumn{1}{|c|}{ Specification } & Amount & Interest rate & $\begin{array}{c}\text { The market rate } \\
\text { (in\%) }\end{array}$ & $\begin{array}{c}\text { Daily money market rate } \\
\text { (in\%) }\end{array}$ \\
\hline Assets \\
\hline Cash and a bill at the central bank & 150,00 & 0,00 & 0,00 & 16,00 \\
\hline Receivables from clients (12M) & 650,00 & 24,50 & 18,00 & 16,00 \\
\hline Securities (6M) & 200,00 & 19,00 & 19,50 & 16,00 \\
\hline Total assets & 1000,00 & 19,725 & 15,600 & 16,000 \\
\hline liabilities & \multicolumn{5}{|l}{} \\
\hline Depositsa vista & 320,00 & 7,00 & 16,00 & 16,00 \\
\hline Term deposits (6M) & 550,00 & 19,50 & 19,50 & 16,00 \\
\hline Issued securities (6M) & 130,00 & 17,50 & 19,50 & 16,00 \\
\hline Total liabilities & 1000,00 & 15,240 & 18,380 & 16,00 \\
\hline
\end{tabular}

Source: own study based on Iwanicz-Drozdowska 1999, p. 117.

The calculation of the margin in this case should start with calculating the interest surplus. The results are shown in Table 14.

Table 14. Interest surplus - market interest method

\begin{tabular}{|l|r|r|}
\hline \multicolumn{1}{|c|}{ Specification } & Amount & \multicolumn{1}{c|}{$\%$} \\
\hline Interest income & 197,25 & 19,725 \\
\hline Interest costs & 152,40 & 15,240 \\
\hline Interest surplus & $\mathbf{4 4 , 8 5}$ & $\mathbf{4 , 4 8 5}$ \\
\hline
\end{tabular}

Source: own study based on Iwanicz-Drozdowska 1999, p. 122.

The calculation of benefits resulting from market conditions is presented in Table 15.

While calculating the benefits resulting from market conditions, the market interest rate was deducted from the obtained interest, whereas in the case of liabilities, the interest rate was deducted from the market interest rate. The last part of the calculation is to determine the benefits of the transformation of terms by referring to the daily money interest. These calculations are given in Table 16. 
Table 15. Benefits from market conditions

\begin{tabular}{|l|r|r|}
\hline \multicolumn{1}{|c|}{ Specification } & \multicolumn{1}{|c|}{ Amount } & \multicolumn{1}{|c|}{$\%$} \\
\hline Assets \\
\hline Cash and a bill at the central bank & 0,000 & 0,000 \\
\hline Receivables from clients (12M) & 42,350 & 6,500 \\
\hline Securities (6M) & $-1,000$ & $-0,500$ \\
\hline Total assets \\
\hline liabilities \\
\hline Deposits a vista & 41,250 & 4,125 \\
\hline Term deposits (6M) & 28,800 & 9,000 \\
\hline Issued securities (6M) & 0,000 & 0,000 \\
\hline Total liabilities & 2,600 & 2,000 \\
\hline SUM & 31,400 & 3,140 \\
\hline
\end{tabular}

Source: own study based on Iwanicz-Drozdowska 1999, p. 122.

Table 16. Benefits of the transformation of terms

\begin{tabular}{|l|r|r|}
\hline \multicolumn{1}{|c|}{ Specification } & \multicolumn{1}{|c|}{ Amount } & \multicolumn{1}{c|}{$\%$} \\
\hline Assets \\
\hline Cash and a bill at the central bank & $-24,000$ & $-16,000$ \\
\hline Receivables from clients (12M) & 13,000 & 2,000 \\
\hline Securities (6M) & 7,000 & 3,500 \\
\hline Total assets & $-4,000$ & $-0,400$ \\
\hline liabilities \\
\hline Deposits a vista & 0,000 & 0,000 \\
\hline Term deposits (6M) & $-19,250$ & $-3,500$ \\
\hline Issued securities (6M) & $-4,550$ & $-3,500$ \\
\hline Total liabilities & $-23,800$ & $-2,380$ \\
\hline SUM & $-27,800$ & $-2,780$ \\
\hline
\end{tabular}

Source: own study based on Iwanicz-Drozdowska 1999, p. 123.

The simulation showed that the bank gains the greatest benefits from deposits and vista as well as receivables from customers. Investment securities issued ineffective turned out to be ineffective despite the fact that traditional methods described them as effective. The transformation of deadlines brought losses to the bank (IwaniczDrozdowska 1999, p. 123).

\section{Conclusions}

The assessment of the effectiveness of banking products is very important from the point of view of bank management, which requires making multiple decisions regarding 
both current and strategic goals. Thanks to such calculations, the bank receives information on the quality and usability of individual areas of its operations. This is important because it allows you to increase the rationality of decisions made, which in the longterm affects the growth of the bank's value. The methods of measuring the profitability of interest banking products show that the bank has the option of choosing different calculation methods. As it turns out, none of them is a flawless solution. These methods have both advantages and disadvantages resulting from the use of certain simplifications. The presented measurement methods are part of the bank's efficiency statement, which is one of the controlling instruments. It allows you to evaluate the strengths and weaknesses of interest products and, as a result, their impact on the financial result. It also supports the conduct of pricing policy in the range of services offered.

After comparing the three methods of calculating the profitability of interest products, including bank loans, it can be stated that compared to traditional methods it is more advantageous to use the single pool method, which compares the margins of individual banking products (eg loans) by assessing the profitability of each of them. The stratified balance method allows only for estimating the effectiveness of previously specified balance sheets. However, these methods have a particular drawback, which is the failure to take into account current market conditions. In this respect, the method of market interest rates (market interest) turns out to be more profitable, which, taking into account the current market conditions in the calculation process, allows to estimate whether the transaction executed by the bank was concluded on terms more or less favorable than those prevailing on the market. In addition, it allows you to set a minimum interest rate in terms of achieving the intended result.

In summary, the methods of calculating the profitability of banking products, although not ideal, give a lot of information that allow identifying and developing product groups with the highest profitability, help determine the reasons for the unprofitability of services and search for corrective solutions, as well as control the development of new products. It is important, however, that each bank should develop and operate according to its own system for measuring the profitability of interest services, in line with the specificity of its operations. This is very important because of the possibility of falsifying reality in the event of an incorrect assessment system. This, in turn, may lead to a decline in the profitability of the bank's operations.

\section{References}

Czerwiński T. (2011). Kredyt hipoteczny - przydatne definicje, https://direct.money.pl/artykuly/ kredyty/kredythipoteczny---przydatne-definicje, 171,0,934059.html

Iwanicz-Drozdowska M. (1999). Metody oceny działalności banku, POLTEX, Warszawa. 
Marża, a oprocentowanie kredytu (2018). https://www.finanse21.pl/marza-a-oprocentowanie-kredytu.html (dostęp: 11.04.2018).

Olszewska G.A. (2018). Foreign currency loans and stability of the banking system in Poland, Risk is a common phenomenon in bank activities. "Central European Review of Economics \& Finance", Vol. 25. No. 3.

RRSO. Co to jest? lle naprawdę kosztuje kredyt?, https://metafinanse.pl/co-to-jest-rrso-kredyt-koszty/ (dostęp: 11.04.2018).

Rynkowa stopa referencyjna (2018), https://www.moneymakers.pl/jak-to-dziala/slownik/rynkowa-stopareferencyjna (dostęp: 11.04.2018).

Szadziewska A. (2005), Metody pomiaru opłacalności odsetkowych produktów bankowych a zarządzanie bankiem, https://www.google.pl/url?sa=t\&rct=j\&q=\&esrc=s\&source=web\&cd=1\&c $a d=r j a \& u a c t=8 \& v e d=0$ ahUKEwi6hb7nx8HbAhUDPsAKHUkRD2gQFggnMAA\&url=http\%3A \%2F\%2Fjmf.wzr.pl\%2Fpim\%2F2005_2_20.pdf\&usg=AOvVaw1h Dzan-iPCV-yll3-1qHZI (dostęp: 15.05.2018).

Urząd Komisji Nadzoru Finansowego (2017). Informacja o sytuacji banków w okresie I-IX 2017 r., https://www.knf.gov.pl/knf/pl/komponenty/img/RAPORT_O_SYTUACJI_BAN KOW_ 2017_09_60633.pdf (dostęp: 15.03.2018).

Wąsowski W. (2001). Ekonomika i Finanse banku komercyjnego w zarysie, Biblioteka Menedżera i Bankowca "Zarządzanie i Finanse”, Warszawa. 